\title{
Problems of the Penalization of Ecological Crimes
}

\author{
Yu. V. Nadtochy \\ Far Eastern Federal University, Vladivostok, Russia
}

\section{Doi:10.5901/mjss.2015.v6n6s3p217}

\begin{abstract}
In article are analyzed the criminal precepts of law containing in Chapter 26 of the Criminal Code of the Russian Federation, providing responsibility for ecological crimes in the context of establishment of compliance of their sanctions to character and degree of public danger of the prohibited acts. In work it is emphasized, that efficiency of application of criminal precepts of law, in general, regulations about responsibility for ecological crimes, in particular, depends on many factors to which both lawmaking problems, and law enforcement's belong. In this regard, questions as legislative designing of sanctions of the corresponding criminal precepts of the law, and their practical implementation in the form of the imposed sentence are considered. The analysis of statistical data, materials of criminal cases is for this purpose carried out, the types of ecological crimes that are most put into practice come to light and the direct analysis of sanctions is made. As a result of the conducted research, the conclusion that the majority of sanctions of regulations about responsibility for ecological crimes do not correspond to character and degree of public danger of acts is drawn. Also, it is noted that main types of sentences that are imposed by vessels in this category of affairs are the penalty and incarceration is conditional. In this connection, it is summarized that today it is impossible to recognize the applied punishment measures for ecological crimes effective.
\end{abstract}

Keywords: punishment, penalization, the environment, sanction, ecological crimes.

\section{Introduction}

The ecological situation that developed so far on the planet causes grave concern around the world. Proceeding from these numerous researches in the field of ecology, it is possible to conclude that any global ecological characteristic in recent years did not improve. All natural objects suffer from anthropogenous influence. Every year the volume of the substances polluting environment increases. The enterprises of fuel and energy complex, transport, different engineering enterprises treat the main anthropogenous sources of pollution. In addition to the gaseous contaminating substances, the large number of firm particles comes to the atmosphere (it is dust, the soot and soot). Global pollution of atmospheric air affects the condition of natural ecosystems, especially the green cover of our planet. Technogenic influence of industrial enterprises and objects of municipal services perniciously influences both quality of waters and the condition of water resources. Annually in the Russian Federation more than 16 billion cubic meters of the contaminated sewage, in the atmosphere - more than 19 million cubic meters of the contaminating substances are dumped (Raskina, 2012). By estimates of the Russian experts, the significant amount of the contaminating substances comes to waters from the enterprises of ferrous and nonferrous metallurgy, petrochemical, pulp, and paper industry. Water sources in some regions, in particular, South Ural, are the most contaminated (Aidar, 2015). Intensive pollution of waters results. Also, it is only the little bit of those indicators that illustrate the negative state of the environment, such examples it is possible to give the set. Today the anthropogenous impact of the person on the nature exceeds admissible limits by 10 times, and the quantity of already destroyed ecosystems makes about 40\% (Anisimov, Alekseeva \& Melikhov, 2013).Because of deterioration of the ecological situation the illness rate raises, the health and quality of human life worse, life expectancy decreases, death rate increases. Therefore before humanity there was the task of implementation of the urgent measures directed at prevention of ecological crisis.

It is necessary to carry to the reasons for the designated problems that fact that the long-time criminal legal policy on fight against ecological crimes was developed taking into account the priority of economic requirements over ecological and it leaves the mark on the state of environment to this day. Besides, as the reasons it is necessary to call shortcomings of the legislative regulation of this type of crimes, lack of the proper economic basis for preserving and improvement of environment, the essential factor also is underestimation of public danger of these crimes, after all today ecological crimes belong to category of offences of small and average weight. In comparison with those negative effects that they render on the environment, such situation causes, to put it mildly, bewilderment and the number of natural questions. After all in the criminal code the acts constituting the greatest public danger as criminal liability is the extreme, 
most drastic measure of influence and the corresponding these acts are recorded their public danger shall be punished adequately.

All above testifies that the problem of conservation is one of the major problems in which decision the significant role is allocated for criminal law. It also causes the research subject choice.

Probably, understanding the importance of the solution of environmental problems, many scientists even more often touch in recent years upon this theoretically and upon the most important subject. So, ecological crimes in general were studied from different positions and found the reflection in works of such scientists, as M. M. Brinchuk, T.A. Bushuyeva, E.V. Vinogradov, P. S. Dagel, O. L. Dubovik, A.E. Zhalinsky, E.N. Zewlakow, N. A. Lopashenko, Yu.I. Lyapunov, VA.Nersesyan, V.D. Pakutin, V. V. Petrov, A.M. Pleshakov, P.F. Povelitsina, N. L. Romanova, I.M. Tyazhkova, B. V. Yatselenko and many others. However in the majority the main attention in them was paid or to the development of the general system of these crimes, or consideration of single questions by the general doctrine about corpus delicti.

Some scientists consider narrower aspects of the designated subject, in particular there are researches devoted: to criminal legal protection of waters from pollution (for example, I.V. Popov, A.Yu. Filanenko, N. A. Chertova), to problems of criminal liability for illegal production of water biological resources and illegal hunting (for example, A.A's theses. Person on duty, A.I. Isaeva, A.M. Kablov, S.E. Kalenova, A.M. Maximova, O. M. Neudakhina, I.A. Parshina, V. G. Pushkarev, V. M. Radnayev, V.A. Cherepakhin, etc.), forest conservation (D. V. Basayev, V. N. Kaplunov, A.A. Lachin, N. A. Sokolov, etc.).

All this only emphasizes the relevance of the subject. Without belittling the importance of the specified works, we want to note that the subject of research stated by us in this work is concrete and original that covers all structures of ecological crimes from the position of nature of their punishability that allows to carry out deeper and detailed analysis not of simply regulations, and to investigate their sanctions from the point of view of the legislative regulation and practical implementation. In the course of establishment of nature of punishability of crimes, the legislator shall reflect adequately in the ideal the sanction character and degree of public danger of the prohibited act. Unfortunately, such adequacy manages to be reached not always. From here also there is the need for their research (Balandyuk, 1998).

Besides, in work all last changes of the penal legislation in this sphere connected both with the criminalization of new structures of crimes and with changes of sanctions of the relevant standards are considered.

Research purposes consist in that on the basis of the analysis of regulations of the criminal code of Russian Federation about responsibility for ecological crimes, the opinions expressed in the doctrine of criminal law of statistical data, materials of court practice to develop suggestions for improvement of sanctions of the corresponding criminal precepts of law, and also the provisions promoting purpose of effective punishment in court practice for improvement of fight against ecological crime.

For achievement of these purposes the following tasks are set: show the state, structure and dynamics of development of ecological crimes, to establish their most widespread types, to analyze sanctions of regulations about responsibility for ecological crimes, to reveal problems and to offer ways of their decision.

The object of research are the public relations developing in the field of application of criminal precepts of law about responsibility for ecological crimes. Regulations of the penal legislation ( $\mathrm{hl}$ act as the object of research. 26 criminal codes of Russian Federation); practice of purpose of punishment for crimes, statistical data, and also scientific publications on the studied perspective.

For achievement of the effective objective author's approach was developed. Which essence consists that in the beginning the analysis of statistical data on responsibility for ecological crimes, for identification of the state, structure, and dynamics of this type of crimes is carried out, further all ecological crimes share on groups, agrees the commonly accepted classification in the theory of criminal law, for convenience of the analysis and determination of tendencies of punishability of different groups of crimes. Then the direct analysis of sanctions is carried out and on this basis practical conclusions are drawn.

\section{Methods}

Research work is based on the use of a set of methods that causes receipt of the high-quality and complete information. The methodological basis, in particular, general-logical methods (the analysis, synthesis), dialectic, historical, logo-legal, comparative and legal, statistical, sociological make, expert evaluations, the documentary method, etc.

So, using the statistical method information on the quantity of ecological crimes in general across Russia from 1997 for 2014 was collected and generalized. Thus collecting of primary information from the statistical recordings which are available in bodies of the Ministry of Internal Affairs, prosecutor's office and court and provided on the corresponding information sites and also from materials of criminal cases was initially carried out. Then the report and group of all mass 
of collected data of primary accounting is made. At group such indicators as were used: year, type of the ecological crime, and also punishment measure. As a result on the basis of the analysis of the collected and grouped data on the quantity of ecological crimes data for efficiency evaluation of the operating system of measures of the fight against ecological crime were obtained (Ecological crimes: nauch, 2009).

Studying of materials of criminal cases (documentary method) allowed to generalize the available court practice, to designate the penalization tendencies created in the practice of application of criminal precepts of law about responsibility for ecological crimes.

We studied by selective research 591 sentences of court on the crimes connected with illegal production of water biological resources ( Art. 256, p.1 Art. 253 of the criminal code of Russian Federation) and the illegal cabin of forest plantings from 1997 for 2005, 230 materials of criminal cases on Russia from 2006 for 2014. As a result of the conducted research of criminal cases certain interesting tendencies in nature of punishability are revealed of which it was will be a question below.

\section{Results and Discussion}

Proceeding from the data which are available statistical (in particular, data of Federal State Statistics Service) the condition of ecological crime in general across Russia looks as follows. In 1997 in the country 6971 ecological crimes, in $1998-8628$, in $1999-12413$, in $2000-14818$, in 2001 - 17128, in $2002-21429$, in $2003-26096$, in $2004-30573$, in 2005 - 33491, in 2006 - 41883, in 2007 - 41242, in 2008 - 44883 were registered; in 2009 - 46607; in 2010 - 39155; in 2011 - 29151; in 2012 - 27583; in 2013 - 24728; in 2014 - 25566. Apparently from the provided data throughout the studied period till 2009 the tendency of steady increase in some the registered ecological crimes inclusive was observed (we saw some lowering only in 2007).

Since 2010 and for the present there is the decrease in these indicators. In our opinion decrease is caused by changes in criminal policy in this sphere, aspiration on ensuring ecological safety, improvement of the ecological and penal legislation in the field of environmental protection. So, in 2012 Bases of the state policy in the field of ecological development of the Russian Federation for the period till 2030 are approved, their development is caused by need of ensuring ecological safety at modernization of economy and in the course of its innovation development (Dokipediya: Criminal law as instrument for ensuring of ecological safety).In 2010 the Resolution of Plenum of the Supreme Court of the Russian Federation "About some questions of application by vessels of the legislation on criminal liability in the field of fishery and preserving of water biological resources (article 253, 256 of the criminal code of Russian Federation)", in 2012 the new Resolution of Plenum of the Supreme Court of the Russian Federation "About application by vessels of the legislation on responsibility for violations in the field of environmental protection and environmental management" is accepted. It is also necessary to mention that in September, 2013 at last, bases of the state policy in the field of use, protection, protection and reproduction of the woods of the Russian Federation for 2030 where the principles are defined, the purposes, tasks and the mechanism of implementation of the state policy in this sphere are approved, the number of changes is brought in the penal statute. Big changes happened in the field of protection of rare, disappearing organisms of which criminalization of new corpus delicti (Art. 258.1 of the criminal code of Russian Federation was result "Illegal production and turnover of especially valuable wild animals and water biological resources belonging to the types included in the Red List Russian Federation and (or) protected by international treaties of the Russian Federation). As we see the hard work in this direction is conducted.

Meanwhile, according to some specialists current situation is more the consequence of weak state control and protection of natural resources, deficiencies of the ecological legislation, almost general public apathy to violators of the law (Raskina, 2012, p. 63). It is necessary to agree with it. After all despite such indicators of a decrease in ecological crime it should be noted that complete and reliable information about the committed ecological crimes, unfortunately, is not present now. According to the experts, the latency of ecological crime is considered one of the highest and makes 95 - 99\%. And if according to statistic reports ecological crimes, occupy one with small percent from total quantity of the criminal actions achieved in the country (and it remains it is stable throughout the studied period), actually, taking into account latency, their quantity makes according to some information 3-5\% (Zhadan, 2013), and on another comes nearer to $15-23 \%$ (Zewlakow, 1996).

Structurally, ecological crimes are provided by generally illegal cabin of forest plantings (Art. 260 of the criminal code of Russian Federation) which is the leader in number of the registered crimes (14834 in 2014) and illegal production of water biological resources (Art. 256 of the criminal code of Russian Federation), not much more to it conceding and taking the second place (6566). Illegal hunting (Art. 258 of the criminal code of Russian Federation) and destruction or damage to forest plantings (Art. 261 of the criminal law of Russian Federation), considerably conceding to the first to two, 
take the third position (1615 and 1381). As the catching up Art. 258.1 of the criminal code of Russian Federation (illegal production and turnover of especially valuable wild animals and water biological resources belonging to the types included in the Red List Russian Federation and (or) protected by international treaties of the Russian Federation) entered into the criminal code of Russian Federation only in 2013 and very actively gaining steam (924) acts now. The practice of application of other structures is insignificant. On some structures, she aims at zero or is equal to zero (Art. 248, 259 of the criminal code of Russian Federation).

Having defined the main tendencies and indicators of ecological crime and, having revealed the circle of the most applied structures, we will pass to the characteristic of sanctions of these regulations. For convenience of the further analysis, it is advisable to divide all structures of ecological crimes into groups. For this purpose, we addressed to the classifications of ecological crimes, which are available in the theory of criminal law. It is offered to classify them depending on the direct object and the subject of encroachment. One of the most widespread is the position of division of all structures of ecological crimes into crimes of the general character (which encroach on surrounding environment in general) and special ecological crimes (which do harm to separate components of environment).

As a rule, refer the criminal actions provided by articles 246-249 of the criminal code of Russian Federation to ecological crimes of the general character of special - articles 250-262 UK (A.G. Knyazev, D.B. Churakov, A.I. Chuchayev, 2009). Special ecological crimes in group classify depending on the type of the subject of encroachment. Most of specialists (though here also there is no unity of opinions) suggest to allocate the crimes encroaching on the public relations in the field of protection of the earth and the subsoil (Art. 253, 254, 255 of the criminal code of Russian Federation); the crimes encroaching on the public relations in the field of protection of fauna (p.1 Art. 249, the Art. of Art. $256,257,258,259$ of the criminal code of Russian Federation); the crimes encroaching on the public relations in the field of protection of flora (h. 2nd Art. 249, Art. 256, 260, 261 of the criminal code of Russian Federation); the crimes encroaching on the public relations in the field of protection of waters and the atmosphere (Art. 250-252 of the criminal code of Russian Federation).

For the purposes of our research, it is represented correctly to adhere to the commonly accepted classification of the division of ecological crimes on the general and extraordinary. Thus in the first group we carried the crimes provided by the Art. of Art. 246-249 of the criminal code of Russian Federation, and in the second all others.

We divided special ecological crimes taking into account specifics of research only into two big groups, proceeding from the subject of encroachment and prevalence in court practice:

- the crimes encroaching on the public relations in the field of protection of the earth, the subsoil, waters and the atmospheres connected with pollution of these natural objects (the Art. of Art. 250-252, p.1 Art. 253, the Art. 254, 255, 262 of the criminal code of Russian Federation);

- The crimes encroaching on the public relations in the field of protection of the animal and flora connected with withdrawal or destruction of live resources (h. 2nd Art. 253, Art. 256-261 of the criminal code of Russian Federation).

Concerning Art. 253 of the criminal code of Russian Federation (violation of the legislation of the Russian Federation on the continental shelf and about the exclusive economic zone Russian Federation) should be made the clause. The part second of this corpus delicti provides approach of criminal liability for research, the search, investigation, development of natural resources of the continental shelf of the Russian Federation or the exclusive economic zone Russian Federation which is carried out without the corresponding permission. According to Federal Law "About the Continental Shelf of the Russian Federation" of 25.10.1995 and Federal Law "About the Exclusive Economic Zone Russian Federation" of 17.12.1998 these actions belong to lifeless (mineral) resources, however court practice interprets regulation broadly and makes responsible for the similar acts made concerning live resources, in particular equals production of live natural resources with development ( $100 \%$ of the sentences studied by us). For this reason, we placed this regulation in a group of encroachments on animal and flora.

Originally we will stop on sanctions of regulations of the general ecological crimes. Here the resonance between sanctions of Art. 246 of the criminal code of Russian Federation (abuse of regulations of environmental protection at works) and 248 criminal codes of Russian Federation (abuse of regulations of safety is evident in the treatment of microbiological or other biological agents or toxins). In both regulations it is about violation of the certain rules designated in the disposition, effects of these crimes are similar, namely: essential change of the radioactive background, damnification to health of the person, mass death of animals or other heavy effects (according to Art. 246 of the criminal code of Russian Federation) and damnification to health of the person, distribution of epidemics or the epizooty or other heavy effects (according to p.1 Art. 248 of the criminal code of Russian Federation), but Art. 246 of UK belongs to crimes of average weight and p.1 Art. 248 of UK to crimes of small weight. It is represented that the legislator underestimates the degree of public danger of the crime provided by Art. 248 of the criminal code of Russian Federation. And in general, 
speaking about the general ecological crimes, i.e. the crimes encroaching on environment in general and able to do harm at once to many components of environment, it appears, that their public danger is much higher than public danger of special ecological crimes and, respectively, they shall be punished more strictly, but not treat category of crimes small, with rare exception average weight.

As for the analysis of crimes of the separate components of the environment, which are expressed in pollution, here the legislator is rather consecutive in designing of sanctions. All structures of crimes are carried to crimes of small weight and only especially qualified structures (h.3) which are providing responsibility for commission of the corresponding acts entailed causing death on imprudence are carried to crimes of average weight. However, in general, their public danger is also underestimated by the legislator, after all contaminating one natural object, for example waters, harm is also done to other objects, for example water biological resources as all natural objects are interconnected among themselves and this factor needs also to be considered when designing sanctions.

Let's a little more in detail stop on the analysis of sanctions of the second group of special ecological crimes as it is the most applied regulations from all chapter. First of all, we will address the crimes provided h. 2nd Art. 253, Art. 256, 258 of the criminal code of Russian Federation. As we are already designated, in Art. 256 of UK it is about the illegal production of water biological resources and in Art. 258 of UK - about illegal hunting. Designs of articles are similar and provide an approach of criminal liability for the commission of the designated illegal actions in the presence of the signs formulated in items "and -". These signs in both structures are identical, with only that difference that in the item "g" of Art. 256 of UK it is about spawning places and in the item "g" of Art. 258 of UK responsibility for hunting for animals and birds hunting on which is completely prohibited that is caused by specifics of the subject of encroachment is established. A little the St differs from them. 253 criminal codes of Russian Federation "Violation of the legislation of the Russian Federation on the continental shelf and about the exclusive economic zone of the Russian Federation", responsibility on which come for research, the investigation and development of natural resources which is carried out without the corresponding permission. The article is formulated on the basis of the special subject and the place of crime execution, meanwhile, in all designated structures taking into account established practices, it is about poaching.

So, during comparative research of sanctions of the named regulations it is possible to see the following tendencies (table 1).

Table 1 - Comparisons of types and the amount of punishments in sanctions of articles providing responsibility for the crimes encroaching on fauna.

\begin{tabular}{|c|c|c|c|c|c|}
\hline Till 6 months. & p. 2nd Art. 253 & p. 1 Art. 256 & p. 3 Art. 256 & p. 1 Art. 258 & p. 2 Art. 258 \\
\hline Penalty & $\begin{array}{l}\text { From } 100 \text { to } 500 \text { thousand } \\
\text { rubles or the period from } 1 \\
\text { to } 3 \text { years }\end{array}$ & $\begin{array}{l}\text { From } 100 \text { thousand } \\
\text { to } 300 \text { thousand } \\
\text { rubles or the period } \\
\text { from } 1 \mathrm{~g} \text { till } 2 \text { years }\end{array}$ & $\begin{array}{l}\text { From } 100 \text { thousand to } \\
500 \text { thousand rubles or } \\
\text { the period from } 1 \mathrm{~g} \text { till } 3 \\
\text { years }\end{array}$ & $\begin{array}{l}\text { To } 200 \text { thousand } \\
\text { rubles or the } \\
\text { period till } 18 \\
\text { months. }\end{array}$ & $\begin{array}{l}\text { From } 100 \text { thousand to } \\
300 \text { thousand rubles or } \\
\text { the period from } 1 \mathrm{~g} \text { till } 2 \\
\text { years }\end{array}$ \\
\hline Obligatory works & Till 480 hours & Till 480 hours & & Till 480 hours & \\
\hline Corrective works & Till 2 years & Till 2 years & & Till 2 years & \\
\hline Forced labor & & & Till 2 years & & Till 2 years \\
\hline Arrest & & Till 6 months. & & Till 6 months. & \\
\hline Imprisonment & & & Till 2 years & & Till 2 years \\
\hline $\begin{array}{l}\text { Deprivation of the right to hold } \\
\text { certain positions or to be } \\
\text { engaged in the certain activity }\end{array}$ & $\begin{array}{l}\text { Perhaps as the auxiliary } \\
\text { view of punishment for a } \\
\text { period of up to } 3 \text { years }\end{array}$ & & $\begin{array}{l}\text { Perhaps as the auxiliary } \\
\text { view of punishment for a } \\
\text { period of up to } 3 \text { years }\end{array}$ & & $\begin{array}{l}\text { Perhaps as the auxiliary } \\
\text { view of punishment for a } \\
\text { period of up to } 3 \text { years }\end{array}$ \\
\hline
\end{tabular}

The list of possible alternative types of punishment in them is identical that is quite logical, also their sizes except for the sizes of the penalty which according to p.1 Art. 258 of the criminal code of Russian Federation slightly lower and has no lower bound match, and it means that the court can appoint the minimum size of the penalty provided by the General part of the criminal code of Russian Federation. Moreover, here, it is not quite clear to us, than such discrepancies are caused.

Besides, speaking about penalties, it is represented that its sizes are very low. After all, proceeding from the punishment purposes, it shall stimulate the violated right, guilty to recovery, to smoothing down of the done harm, thereby strengthening the educational orientation, promoting elimination of the reasons of the committed crime and not commission of similar acts in the future.

For anybody, not the secret that illegal trade is very profitable business in our country. In comparison with the income, which is gained by poachers from the sale of illegally, got products abroad, the penalties levied from them it is insignificant are small. It is clear that the poacher cannot pay them and to continue the illegal business. As it is noted in 
scientific literature, the ecological crime becomes more and more dangerous and more profitable: so-called trade in environment (from the illegal import and export of objects of the animal and flora included in the Red List before illegal burial in the territory of Russia of radioactive, nuclear and other dangerous wastes) starts competing with such most profitable and cost-effective types of criminal activity as drug trafficking and arms trade (Kachina \& Mironchik, 2014).

Due to the above, for the purpose of more efficient fight against similar acts, we consider necessary to increase the penalty sizes, and to bring them into accord with degree of public danger so that they adequately reflected features of the considered corpus delicti.

Further is evident, that custodial sanction does not appear in the main structures of the studied sanctions of articles. Respectively the stiffest punishment for similar actions according to the existing penal statute is an arrest. However, as we know, arrest as the type of punishment is not applied now. Told means that either corrective or obligatory works, or the penalty actually can punish the considered crimes. In these cases the severity of punishment, in our opinion, obviously does not correspond to the danger of deeds. Moreover, in $\mathrm{h}$. The 2nd Art. 253 of the criminal code of Russian Federation, in general, is not present the even formally fixed such type of punishment as arrest, here the most severe looking are the corrective works appointed for a period of up to two years.

It is represented that establishment of the minimum terms of deprivation of freedom even will serve in the main structures to the achievement of goals of punishment and, first of all, the purposes of the general prevention. Let's note that offers of this sort even more often express in the scientific literature (Bratashova, 2011).

Further, it is interesting to compare these sanctions to Art. 258.1 of the criminal code of Russian Federation establishing responsibility for illegal production and turnover of especially valuable resources. We see that having criminalized this regulation, the legislator considerably strengthened responsibility, having established a tough sanction rather. Already in p.1 there is such type of punishment as incarceration for up to three years, the penalty it is possible to impose sentences only as the auxiliary view. It is necessary to support such step of the legislator, as it is obvious that public danger of the crime provided by Art. 258.1 of UK is much higher because in it is about especially valuable animal species, which are under the protection of the state.

Let's address to the qualified structures now. In sanctions of all three articles as we see, already there is such type of punishment as incarceration. However, the crimes provided of the Art. of Art. 256, 258 of the criminal code of Russian Federation remain crimes of small weight even if the person makes them with the use of the official position or the group of persons by previous concert or organized group. If to look at Art. 258.1 of UK, we will see that there was the differentiation on the qualified - in case of crime execution by the official, and specially qualified - if the organized group worked. Thus in the first instance is the crime treats category of average weight and it is punished by incarceration till 5 years, and in the second case is the already serious crime prescribing custodial sanction till 7 years. There is the question why the legislator did not provide similar differentiation and in the station of St. 256 and 258 UK where act of the official and action of the organized group of persons can be most punished by two years of imprisonment? Here at once underestimation of public danger of these crimes is visible. The increase in terms of deprivation of freedom for these crimes can be the exit from the created provision.

Now we will compare the sanction of Art. 258.1 of the criminal code of Russian Federation to the sanction of Art. 259 of the criminal law of Russian Federation "Destruction of critical habitats for the organisms included in the Red List of the Russian Federation" as they are also in some way similar to themselves.

The sanction of Art. 259 of the criminal code of Russian Federation is rather soft; this crime is referred by the legislator to the category of crimes of small weight. Let's look at this article more attentively now. Here it is necessary for occurrence of responsibility not only commission of act, i.e. destruction of the critical habitat, but also approach of effects in the form of death of populations of the organisms included in the Red List. It turns out that rare animals using destruction of the place of their dwelling are destroyed. If we destroy one "Red Book" animal - we qualify such actions according to Art. 258.1 of UK, we destroy population - according to Art. 258.1 of UK, we destroy the habitat therefore population Moreover and not one - according to Art. 259 of the criminal code of Russian Federation perishes. Thus maximum punishment in all cases - incarceration till three years. The similar situation is, to put it mildly, surprising. It is represented that in that case the sanction of Art. 259 of the criminal code of Russian Federation shall be much higher.

Addressing to Art. 257 of the criminal code of Russian Federation "Abuse of regulations of protection of water biological resources" it is possible to see the same tendencies (it, besides, the crime of small weight). Only is remarkable that such type of punishment as deprivation of the right to hold certain positions or to be engaged in the certain activity possibly to appoint not only as additional, but also as the main type of punishment.

The biggest sanctions are established in the station of Art. 260, 261 of the criminal code of Russian Federation devoted to forest conservation (Table 2). 
Table 2. Comparisons of types and the amount of punishments in sanctions of articles providing responsibility for the crimes encroaching safety of forest fund.

\begin{tabular}{|c|c|c|c|c|c|c|c|}
\hline Type of punishment & p.1 Art. 260 & H. 2nd Art. 260 & H. 3rd Art. 260 & P.1 Art. of Art. 261 & H. 2nd Art. 261 & H. 3rd Art. 261 & H. 4th Art. 261 \\
\hline Penalty & $\begin{array}{l}\text { to } 500 \\
\text { thousand } \\
\text { rubles or the } \\
\text { period till } 3 \\
\text { years }\end{array}$ & $\begin{array}{l}\text { From } 500 \text { thousand } \\
\text { to } 1 \text { million rubles or } \\
\text { the period from } 3 \text { to } \\
4 \text { years }\end{array}$ & $\begin{array}{l}\text { From } 1 \text { million to } 3 \\
\text { million rubles or the } \\
\text { period from } 4 \text { to } 5 \\
\text { years }\end{array}$ & $\begin{array}{l}\text { From } 200 \text { thousand } \\
\text { to } 400 \text { thousand } \\
\text { rubles or the period } \\
\text { from } 1 \text { to } 2 \text { years }\end{array}$ & $\begin{array}{l}\text { From } 300 \text { thousand } \\
\text { to } 500 \text { thousand } \\
\text { rubles or the period } \\
\text { from } 2 \text { to } 3 \text { years }\end{array}$ & $\begin{array}{l}\text { From } 500 \\
\text { thousand to } 1 \\
\text { million rubles or } \\
\text { the period from } 3 \\
\text { to } 4 \text { years }\end{array}$ & $\begin{array}{l}\text { From } 1 \text { million } \\
\text { to } 3 \text { million } \\
\text { rubles or the } \\
\text { period from } 4 \\
\text { to } 5 \text { years }\end{array}$ \\
\hline Obligatory works & Till 480 hours & & & Till 480 hours & Till 480 hours & & \\
\hline Corrective works & Till 2 years & & & Till 2 years & Till 2 years & & \\
\hline Forced labor & Till 2 years & Till 4 years & Till 5 years & Till 3 years & Till 4 years & & \\
\hline Imprisonment & Till 2 years & Till 4 years & Till 5 years & Till 3 years & Till 4 years & Till 8 years & Till 10 years \\
\hline $\begin{array}{l}\text { Deprivation of the right to } \\
\text { hold certain positions or } \\
\text { to be engaged in the } \\
\text { certain activity }\end{array}$ & & $\begin{array}{l}\text { Perhaps as the } \\
\text { auxiliary view of } \\
\text { punishment for a } \\
\text { period of up to } 3 \\
\text { years }\end{array}$ & $\begin{array}{l}\text { Perhaps as the } \\
\text { auxiliary view of } \\
\text { punishment for a } \\
\text { period of up to } 3 \\
\text { years }\end{array}$ & & & & \\
\hline
\end{tabular}

We see that here rather high sizes of the penalty, especially for the qualified and specially qualified structures of crimes are established. It is represented that to such limits it is necessary to lift also penalties in the station of Art. 253, 256, 258 of the criminal code of Russian Federation. In all cases it is about poaching and if these actions are made by the group of persons by the previous concert organized by group, the person with use of the official position, in the large or especially large sizes attracting the enormous income for poachers, drastic measures are necessary to make economically unprofitable occupation illegal trade.

Also, that appears in all structures custodial sanctions is remarkable, and terms are much higher than in other structures of ecological crimes here. As we see, the crimes which are expressed in destruction or damage to forest plantings and other plantings by the arson, other all-dangerous method or as a result of pollution or other negative impact and also with causing the legislator refers major damage (ch. 3,4 Art. 261 of the criminal code of Russian Federation) to category of serious crimes.

In general, we will note that carrying the ecological rights of citizens to constitutional, the legislator, nevertheless, considers ecological crimes as acts of small public danger. In our opinion, it is not justified at all. The legislator, liberalizing sanctions of the considered regulations, obviously underestimates the crisis that developed in the field of conservation. The current situation in the field of conservation demands the introduction of more drastic measures of responsibility. The legislator needs to think of improvement of the system of punishments for ecological crimes, for the purpose of elimination of the available discrepancies and adequate reflection of character and degree of public danger of the considered crimes.

Not smaller interest is represented by the practical component of the process of the penalization of the studied crimes, which is features of their punishability in court practice. What these features in what tendencies in the practice of application of different types of punishment for the commission of ecological crimes consist?

As a result of the conducted research of criminal cases on all structures of crimes entering hl of 26 penal codes of Russian Federation, we revealed the following interesting tendencies in nature of punishability (table 3).

Table 3. The practice of purpose of punishments for ecological crimes across Russia in $2006-2014$.

\begin{tabular}{|l|c|}
\hline Type of punishment & Specific weight of the condemned persons in \% \\
\hline Imprisonment (real) & 4,8 \\
\hline Imprisonment (conditional) & 43,5 \\
\hline Restriction of freedom & 0,9 \\
\hline Corrective works (real) & 3,0 \\
\hline Corrective works (conditional) & 2,2 \\
\hline Obligatory works & 3,0 \\
\hline Penalty & 45,2 \\
\hline Deprivation of the right to hold certain positions or to be engaged in the certain activity & 5,7 \\
\hline
\end{tabular}

As we see courts appoint two types of punishment, it is the penalty $(45,2 \%)$ and incarceration is conditional $(43,5 \%)$. Thus, today the penalty is the leading type of the imposed sentence for ecological crimes. Here it should be noted that the tendency of infliction of penalty increased in recent years. It occurred due to restriction with the legislator of 
opportunity to vessels to appoint incarceration for the crimes of small weight committed for the first time, and the crime provided by Art. 256 of the criminal code of Russian Federation, making the considerable share in the structure of ecological crime concerns to that. Respectively, if till 2011 for the commission of this crime purpose of custodial sanction conditionally prevailed, now courts for similar acts appoint the penalty if there are no aggravating circumstances.

It is possible to give criminal case as the example on a charge. The father and V. of the son in crime execution provided $\mathrm{h}$. The 3rd Art. 256 of the criminal code of Russian Federation expressed in the illegal production of water biological resources using different ways of mass destruction of water animals in spawning places, the group of persons by the previous concert. Making the decision on the purpose of punishment court taking into account facts of the case (crime execution for the first time, in the absence of aggravating circumstances) taking into consideration p.1 Art. 56 of the criminal code of Russian Federation and the identity of defendants came to the conclusion that correction condemned perhaps without isolation from society and imposed mulctary punishment (Yuryevetsky district court of the Ivanovo region, case 2012).

As for Art. 260 of the criminal code of Russian Federation, here to this day purpose of custodial sanction conditionally (from 63 sentences 54 - incarceration conditionally, is $85,7 \%$ ) completely dominates. It is connected with that such crimes are generally committed by the group of persons by the previous concert, the person with use of the official position, in the large or especially large size, and it already in relation to this structure, crimes of average weight and, respectively, are not present restriction in imprisonment application.

Also it should be noted that from all structures of ecological crimes under this article the main percent of purpose of punishment in the form of deprivation of the right to hold certain positions or to be engaged in the certain activity is. Under other articles, this type of punishment is appointed quite seldom. The similar state of affairs is represented to us wrong. So, if captains of ships (and this category of citizens commits the most of ecological crimes in the field of fishery) accurately knew that at any violation of them will withdraw the captain's certificate, they ten times would think whether it is worth breaking the law.

It is possible to call application of other types of punishment single. Thus the smallest percent $(0,9 \%)$ makes purpose of restriction of freedom, and it is quite explainable as such type of punishment contains only in three corpus delicti (Art. 247, 249, 258.1 of the criminal code of Russian Federation) and, besides, it is applied rather recently only since 2010.

Adhering to our classification we will designate that ecological crimes of the general character, as well as the crime in the field of protection of separate components of environment from different pollution, make the insignificant share in number of ecological crimes. At the same time, in these groups the leading type of punishment is the penalty (62,8\%). Thus if to take the general ecological crimes then except the penalty in some cases imprisonment conditionally is appointed, and among the crimes connected with pollution by the second applied type of punishment corrective works, thus withdrawal from the general indicators of data on the considered groups of crimes of the being of the picture are does not change. It is possible to note that only a percent of infliction of penalty decreases and it on the second group of special ecological crimes will be equalized with conditional condemnation.

Unfortunately, it should be noted that our courts excessively were fond of the purpose of mulctary punishment and conditional condemnation, and alternative types are practically not applied. Also it should be noted that and conditional imprisonment are sentenced to the penalty not only the persons which for the first time committed crimes, but also persons previously convicted, and also the persons operating as a part of group, the group of persons by previous concert and even organized group. Such "impunity" cannot serve achievement of goals of punishment.

\section{Conclusions}

The analysis of ecological crime which is carried out on the basis of the techniques stated in this work in the territory of the Russian Federation from 1997 for 2014 and sanctions of the corresponding criminal precepts of law allowed to reveal the following tendencies.

Today it is possible to note decrease in level of ecological crime that is caused by positive factors, namely changes in criminal policy in this sphere, aspiration on ensuring ecological safety, improvement of the ecological and penal legislation in the field of environmental protection, and negative, in particular by weak state control of protection of natural resources.

The structure of ecological crimes still testifies to dominance of fixing of infringement of water bioresources, objects of fauna, forest resources (Art. 256, 258, 260, 261 of the criminal code of Russian Federation), but not infringement of quality of waters, atmospheric air, lands, etc.;

It is necessary to state underestimation by the legislator of the degree of public danger of ecological crimes. The 
current situation in the field of conservation demands the introduction of more drastic measures of responsibility. The legislator needs to think of improvement of the system of punishments for ecological crimes, for the purpose of elimination of the available discrepancies and adequate reflection of character and degree of public danger of the considered crimes. In particular, it appears, that public danger of the general ecological crimes is much higher than public danger of special ecological crimes and, respectively, they shall be punished more strictly, but not treat category of crimes small, with rare exception average weight. Also we consider necessary, taking into account degree of public danger, to increase the sanction of Art. 259 of the criminal code of Russian Federation, having transferred this crime to the category of the heavy.

It is also obviously necessary to increase the sizes of the penalty and to bring them into accord with a degree of public danger of the prohibited acts to make economically unprofitable criminal activity. In simple structures of poaching it is necessary to establish the minimum terms of deprivation of freedom, in the qualified types to increase them, having transferred to these the crime to category of crimes of average weight and heavy, having differentiated responsibility depending on the qualifying sign.

As a result of the analysis of the tendencies operating in this sphere it is possible to draw the conclusion that the actual punishability will not always be approved with legislative estimates of public danger of the considered crimes, the quantity of cases of purpose of conditional condemnation for their commission is several times higher than number of purposes of real punishment. Incarceration (with its actual departure) is practically not applied to the persons that committed the specified crimes. The revealed broad application of such types of punishment as the penalty and imprisonment is conditional even to persons the previously convicted, and also to people acting as a part of group, the group of persons by previous concert and even organized group, the exceedingly rare alternative sentencing testifies to the inefficiency of the existing system of punishments. Conditional sentencing to every second person who committed the considered crimes cannot promote achievement of goals, facing punishment. In this regard, for the liquidation of false idea of the inhabitant of not punishability of poaching vessels need to reduce the practice of application of suspended sentence.

\section{Acknowledgement}

This research is conducted with the support by the Ministry of Education and Science of The Russian Federation. Public research task 29.763.2014/K.

\section{References}

Aidar, M. Kalimullin (2015) Ecological Problems of Middle Volga in the Second Half of the XXth Century: Historical and Ecological Analysis of Leading Industrial Regions Development // Review of European Studies; Vol. 7, No. 1. Published by Canadian Center of Science and Education. pp. 86-93.

Anisimov, A.P., Alekseeva, A.P. \& Melikhov, A.I. (2013) Actual problems of counteraction of ecological crime in Russia/the Criminological magazine of the Baikal state university of the economy and the right, No. 3. Irkutsk. pp. 80-89.

Balandyuk, V.N. (1998) Ecological crimes: (concept, types, classification). Omsk. pp. 8-9.

Bratashova, N.I. (2011) Criminal and legal and criminological aspects of the fight against crimes in the field of protection of fauna: avtoref. yew ... edging. yurid. sciences. Saratov.

Dokipediya: Criminal law as an instrument for ensuring of ecological safety.http://dokipedia.ru/document/5209423?pid=68.

Zhadan, V.N. (2013) Topical issues of the criminological characteristic of ecological crimes//Young uchenyy. No. 4. pp. 387 - 393.

Zewlakow, E.N. (1996) Ecological crimes and ecological crime. M. White Alvah.

Kachin, N.V. \& Mironchik, A.S. (2014) Ways of increase of efficiency of criminal liability for the illegal cabin of forest plantings//Criminological magazine of the Baikal state university of economy and right, No. 3. Irkutsk. pp. 103-112.

About application by vessels of the legislation on responsibility for violations in the field of environmental protection and environmental management [The electronic resource]: The resolution of Plenum of the Supreme Court of the Russian Federation of October 18, 2012. Access from sprav. - system of law "ConsultantPlus".

Raskina, T.V. (2012) To the question of efficiency of fight against ecological crimes//the Criminological magazine of the Baikal state university of economy and the right, No. 1. Irkutsk. pp. 62-64.

Ecological crimes: nauch. - praktich (2009) benefit / A.G. Knyazev, D.B. Churakov, A.I. Chuchayev; under the editorship of A. G. Knyazev. M.: Prospectus.

Yuryevetsky district court of the Ivanovo region (2012) Criminal case No. 1-40. https://rospravosudie.com. 